www.jmscr.igmpublication.org Impact Factor 5.244

Index Copernicus Value: 83.27 ISSN (e)-2347-176x ISSN (p) 2455-0450 crossref DOI: _https://dx.doi.org/10.18535/jmscr/v4i12.14

\author{
Journal Of Medical Science And Clinical Research \\ IGM Publication \\ An official Publication of IGM Publication
}

\title{
Utility of Osazone Test to Identify Sugars
}

Authors

\section{Dr Tejas Shah, MD, Dr Nikunj Modi, MD}

(Biochemistry), Dept. of Biochemistry, Shri M P Shah Govt Medical College, Jamnagar, Gujarat (India)

Corresponding Author

\section{Dr Tejas Shah}

MD (Biochemistry), Dept. of Biochemistry,

Shri M P Shah Govt. Medical College, Jamnagar, Gujarat (India)

Email: tejas.1112@gmail.com,Mob: 9879061781

\begin{abstract}
Carbohydrates (sugars) are the most abundant organic molecules in nature. Sugars having reducing property react with phenylhydrazine hydrochloride to form characteristic osazones (crystals). These osazones can be correlated with clinical conditions like arabinose in autism, xylose in small bowel disease and galactose in galactosemia. The study aimed to evaluate utility of osazone test to identify sugars by demonstrating characteristic osazone. Study was conducted at Biochemistry department, Shri M P Shah Govt. Medical College, Jamnagar, Gujarat. We selected sugars like glucose, fructose, mannose, galactose, lactose, maltose, arabinose and xylose to demonstrate their osazone. All sugars were made available commercially. 2 grams\% stock solution prepared of each sugars. Osazone test is performed for each sugar in the boiling water bath and noted down the time for appearing of crystals. Then the shape of osazone of each sugar was examined under microscope. We observed that crystals were appeared at specific interval of time during boiling and cooling slowly after boiling. We found characteristic shape of osazone of sugars under microscope. Glucose, fructose, galactose and mannose formed needle shape osazone. Maltose formed sun flower shape osazone. Lactose formed cotton-ball shape osazone. Arabinose formed dense ball needle shape osazone. Xylose formed fine but long needle shape osazone.The study demonstrated characteristic shape of osazone of sugars by performing osazone test. This simple, cheap and less time consuming test can be used to identify and differentiate sugars encountered in clinical practice.

Keywords: Carbohydrates, phenylhydrazine, osazone.
\end{abstract}

\section{INTRODUCTION}

Carbohydrates (Sugars) are defined chemically as aldehyde or ketone derivatives of the higher polyhydric alcohols, or compounds which yield these derivatives on hydrolysis. ${ }^{[1]}$ They have a wide range of functions, including providing a significant fraction of the energy in the diet of most organisms, acting as a storage form of energy in the body, and serving as cell membrane components that mediate some forms of intercellular communication. ${ }^{[2]}$ Sugars are classified as simple and complex. Simple sugars are called monosaccharides which cannot be hydrolyzed into smaller compound. Complex sugars are disaccharides/oligosaccharides/ polysaccharides which can be hydrolyzed to monosaccharides. Sugars having free carbonyl group (either aldehyde or ketone) are called reducing sugars. The osazone reaction was developed and used by Emil Fischer to identify 
aldose sugars differing in configuration only at the alpha carbon. ${ }^{[3]}$ All reducing sugars will form osazones with excess of phenylhydrazine when kept at boiling temperature. Osazones are insoluble. Each sugar will have characteristic crystal form of osazones which can be used to identify and differentiate sugars in biological fluid like urine. ${ }^{[4]}$ By detecting such sugars, correlation can be made with clinical conditions like (a) glucosuria in diabetes mellitus, fructosuria in fructose intolerance/hereditary fructosuria, lactose in lactose intolerance, galactose in galactosemia ${ }^{[5]}$ (b) arabinose in autism/candidiasis ${ }^{[6]}$ and (c) xylose in small bowel disease/malabsorption syndrome. ${ }^{[7,8]}$ Recent study was done to evaluate characteristic osazones of uncommonly encountered sugars. ${ }^{[9]}$ The present study was aimed to evaluate utility of osazone test to identify sugars by demonstrating characteristic osazone.

\section{MATERIAL AND METHODS}

The present observational study was carried out at Biochemistry department during July 2016 to August 2016. As this study did not involve any kind of intervention to living animals, Institutional Ethics Committee permission was not taken. We used commercially available monosaccharides and disaccharides of analytical grade. We selected commonly encountered sugars like glucose, fructose, mannose, galactose, maltose, lactose along with uncommonly encountered sugars like arabinose and xylose for study.

\section{Principle of osazone test: ${ }^{[9,10]}$}

Reducing sugar reacts with one molecule of phenylhydrazine hydrochloride $\left(\mathrm{C}_{6} \mathrm{H}_{5}-\mathrm{NH}-\mathrm{NH}_{2}\right)$ to form phenylhydrazone hydrochloride. This complex reacts once again with another molecule of phenylhydrazine hydrochloride to give an intermediate keto derivative. This again reacts with one more molecule of phenylhydrazine hydrochloride to give corresponding osazone. This reaction is complete in 3 steps and consumes 3 moles of phenylhydrazine. During reaction with monosaccharides, additional phenyl hydrazine is consumed in oxidizing the adjacent $\mathrm{OH}$-group to carbonyl group which then forms a second phenyl hydrazone. Such bisphenyl hydrazones are called osazones.

Sugar + phenylhydrazine hydrochloride $\rightarrow$ (sugarphenylhydrazone) $+\mathrm{H}_{2} \mathrm{O}$

sugar-phenylhydrazone +2 (phenylhydrazine hydrochloride) $\rightarrow$ osazone $+\mathrm{C}_{6} \mathrm{H}_{5} \mathrm{NH}_{2}+\mathrm{NH}_{3}+\mathrm{H}_{2} \mathrm{O}$

\section{Procedure: ${ }^{[11,12]}$}

1. Preparation of stock solution; We weighed 2 grams (gm) of each sugar and took it into sterile glass beaker of $150 \mathrm{ml}$ capacity. Then added distilled water to make total volume $100 \mathrm{ml}$. Thus each sugar stock solution ( 2 gm\%) was prepared.

2. Preparation of phenylhydrazine mixture: 1 part of phenylhydrazine hydrochloride mixed with 2 parts of sodium acetate in a mortar.

3. Osazone test: We took $5 \mathrm{ml}$ of sugar stock solution in sterile test tube. Then we added 1 gm of phenylhydrazine hydrochloride mixture and 2 drops glacial acetic acid (to maintain $\mathrm{pH}$ of the solution) into it. Then after mixing well, we put test tube into boiling water bath and noted down the time for appearance of osazone crystal.

4. Microscopic examination: 2 drops of sugar crystals were taken by sterile glass pipette and carefully placed on the glass slide. Then cover slip was placed above it and examined under high resolution microscope. After clear vision of crystals, snapshots were taken for record.

\section{RESULTS}

The present study was performed on 6 monosaccharides (glucose, fructose, mannose, galactose, arabinose, xylose) and 2 disaccharides (maltose, lactose). When observation made, crystals were formed after specific time interval either by boiling or by cooling slowly after boiling. When examining under microscope, characteristic crystals were found. They were shown from figure 1 to 8 . Table 1 showed characteristics of osazone studied. 


\section{JMSCR Vol||04||Issue||12||Page 14361-14365||December}

Table 1. Characteristics of osazone studied

\begin{tabular}{|l|c|c|c|c|}
\hline Name of sugar & Shape of crystal & \multirow{2}{*}{$\begin{array}{c}\text { Time required for crystal } \\
\text { formation (min) }\end{array}$} & \multicolumn{2}{|c|}{ Physical conditions } \\
\cline { 3 - 4 } & & 6 & Boiling & Cooling slowly after boiling \\
\hline Glucose & Needle & 4 & + & ++ \\
\hline Fructose & Needle & 10 & + & ++ \\
\hline Mannose & Needle & 10 & + & ++ \\
\hline Galactose & Balls with thorny edge & 15 & + & ++ \\
\hline Arabinose & Dense ball needle & 15 & - & ++ \\
\hline Xylose & Fine-long needle & 30 & - & ++ \\
\hline Maltose & Sun flower & 30 & + \\
\hline Lactose & Cotton-ball & & + \\
\hline
\end{tabular}

$+=$ appearance of crystal, $++=$ intense appearance of crystal, $-=$ no appearance of crystal.

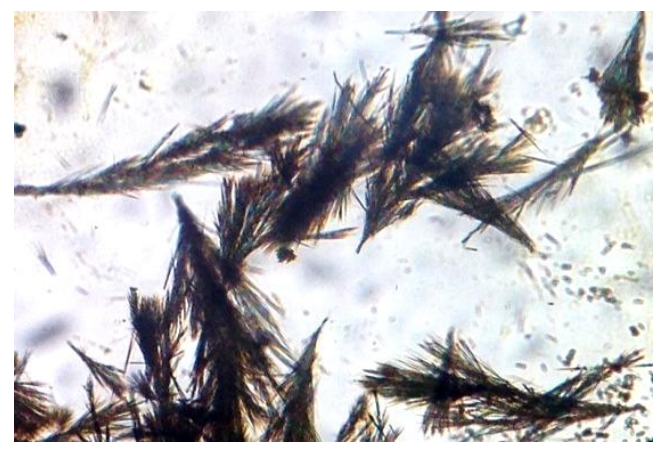

Figure 1. Needle shaped crystals (Glucose)

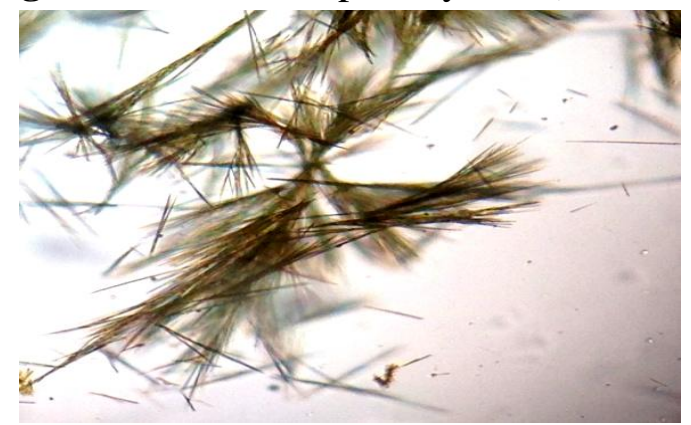

Figure 2. Needle shaped crystals (Fructose)

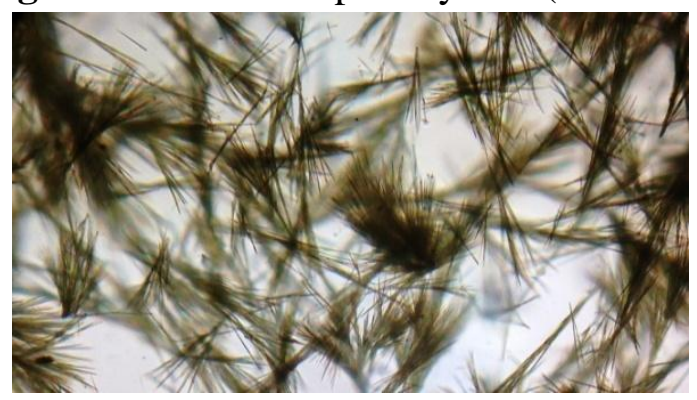

Figure 3. Needle shaped crystals (Mannose)

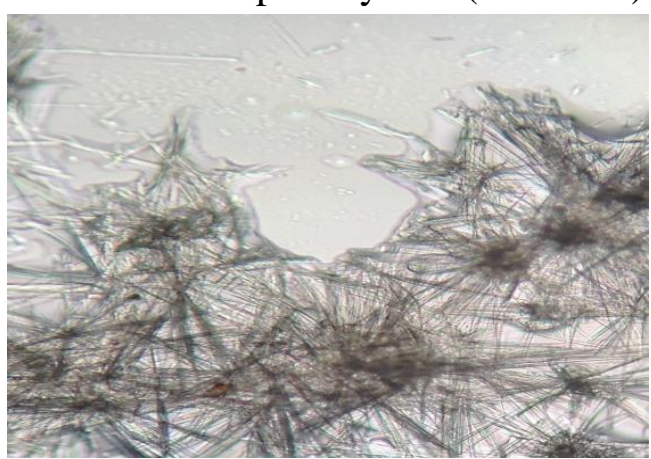

Figure 4. Balls with thorny edge shaped crystals

(Galactose)

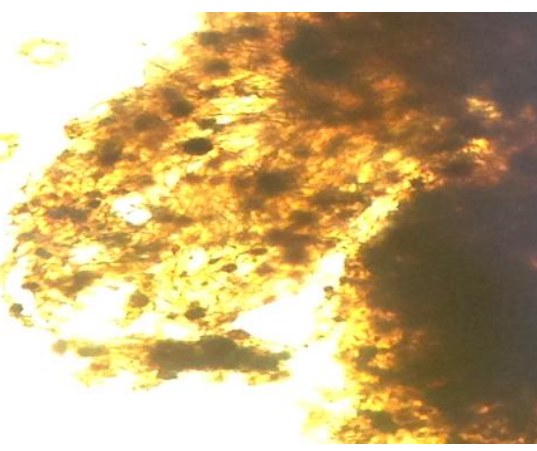

Figure 5. Dense ball needle shaped crystals (Arabinose)

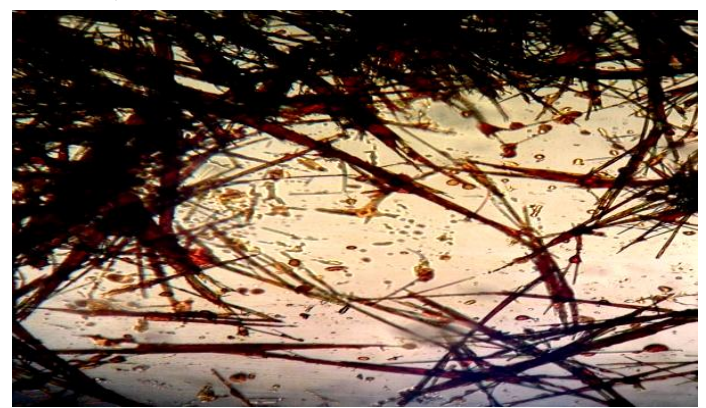

Figure 6. Fine-long needle shaped crystals (Xylose)

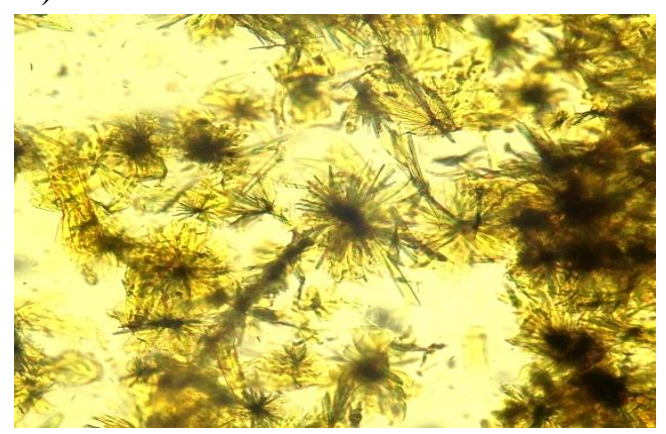

Figure 7. Sun flower shaped crystals (Maltose)

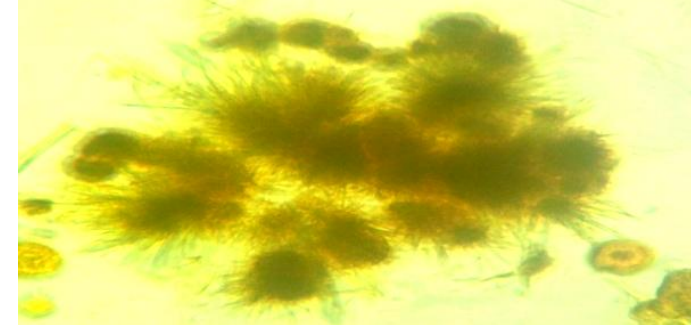

Figure 8. Cotton ball shaped crystals (Lactose) 


\section{DISCUSSION}

Carbohydrates (sugars) are the most abundant biological molecules. ${ }^{[13]}$ Glucose is the major metabolic fuel of mammals (except ruminants) and a universal fuel of the fetus. It is the precursor for synthesis of all the other carbohydrates in the body. Biologically, the most important epimers of glucose are mannose (epimerized at carbon 2) and galactose (epimerized at carbon 4). Fructose has the same molecular formula as glucose but differs in that there is a potential keto group in position 2. Chemically, sugars are reducing compounds if they have free carbonyl group, and are sometimes known as reducing sugars. This provides the basis for a simple chemical test for glucose in urine in poorly controlled diabetes mellitus. ${ }^{[14,15]}$ One of these tests is osazone test. ${ }^{[3]}$ Osazone test is the simplest test to identify and differentiate reducing sugars in biological fluid like urine. It is routinely performed for glucose, fructose, mannose, maltose and lactose. Monosaccharides are powerful reducing agent in hot solution. ${ }^{[4,9]} \mathrm{We}$ found yellow, needle shaped crystals of glucose, fructose and mannose while balls with thorny edge shaped crystals of galactose (refer figure 1 to 4). Glucose, mannose and fructose due to similarities of structures form the same osazones. But since the structure of galactose differs on C-4, that part of the molecule unaffected in osazone formation, it would form a different osazone. ${ }^{[1,16]}$ Because of forming same shaped osazones, it is difficult to differentiate glucose, fructose, and mannose. But time of appearance of crystals may have some utility in diagnosing diabetes and fructose intolerance. Lactose and maltose are reducing disaccharides because beta $(1 \rightarrow 4)$ and alpha $(1 \rightarrow 4)$ glycosidic linkages seen respectively spare carbonyl carbon so that both form osazones. ${ }^{[4]}$ Lactose formed cotton-ball shaped crystals and maltose formed sun flower shaped crystals only after cooling slowly in present study (refer figure 5 and 6). Osazones of reducing disaccharides are more soluble in hot solution and don't appear during boiling. Hence they formed crystals slowly on cooling the solution. $\left.{ }^{[1,} 16\right] \mathrm{We}$ have also examined uncommonly encountered monosaccha- rides like arabinose and xylose. Both are five carbon sugars found in plant gums, proteoglycans and glycosaminoglycans. They are constituent of glycoproteins. ${ }^{[14]}$ We observed dense ball needle shaped and fine-long needle shaped crystals of Arabinose and xylose respectively (refer figure 7 and 8). It is suspected that the arabitol produced by the yeasts in the gastrointestinal tract is absorbed in the portal circulation, and is then converted into arabinose by the liver. It is not metabolised endogenously and is eliminated by the urine. Arabinose is often found to be raised in the presence of intestinal candidiasis, and is commonly found in autistic children. It is suspected that autistic children may have deficiencies of one or more enzymes that are involved in the metabolism of pentoses. High levels of arabinose have been found linked to proteins in serum glycoproteins of serum of schizophrenic patients and in children with behavioural disorders. ${ }^{[6]}$ Xylose is absorbed unchanged by the duodenum and jejunum. Its incomplete absorption allows for its possible use as a malabsorption test or to identify small bowel mucosal disease. ${ }^{[7,8,17]}$ The findings of this study were supported by Vinod BS et al study. ${ }^{[9]}$ For more evaluation high pressure liquid chromatography (HPLC) is used nowadays which not only differentiate but quantify such sugars. ${ }^{[18]}$ In the absence of HPLC setup osazone testing can be utilized.

\section{CONCLUSION}

We demonstrated characteristic osazone of commonly and uncommonly encountered reducing sugars. Osazone test have great utility to identify and differentiate such sugars. Moreover, it is a simple, less time consuming and easily performed in laboratory by technician as compared to HPLC.

\section{LIMITATIONS}

We did not performed osazone test on urine samples of patients. So it is difficult to evaluate the factors which can affect the crystal formation in actual diseased condition. 


\section{ACKNOWLEDGEMENTS}

We are thankful to Mr. M H Rajapara and Mr. Manish Pandya, laboratory technicians, Biochemistry department, Shri M P Shah Govt. Medical College, Bhavnagar for their help and support during this study.

\section{Source of support: None}

\section{REFERENCES}

1. Chatterjee $\mathrm{MN}$, Shinde R, editors. Textbook of medical biochemistry. $8^{\text {th }}$ ed. Ajanta offset \& Packagings Ltd:Jaypee;2012:p.23-8.

2. Ferrier DR, editor. Lippincott's illustrated reviews Biochemistry. $6^{\text {th }}$ ed. Lippincott William \& Wlikins: Wolters Kluwer; 2014:p.83-5.

3. Internet source: http://www2.chemistry.msu.edu

4. Vasudevan DM, Shreekumari S, Vaidyanathan K, editors. Textbook of biochemistry for medical students. $7^{\text {th }}$ ed. Ajanta offset \& Packagings Ltd, Jaypee; 2013:p.69-74.

5. Dennis LK, Eugene B, Anthony SF, Stephen LH, Dan LL, Larry J, editors. Harrison's principles of internal medicine. $16^{\text {th }}$ ed. McGraw-Hill; 2005:p.2319-23.

6. http://www.labco.es/media/pdf/en_downlo ad_13.pdf. Arabinose test for the Diagnosis of intestinal Candidiasis: Labco quality diagnostics.

7. Christie DL. Use of the one-hour blood xylose test as an indicator of small bowel mucosal disease. The Journal of Pediatrics. 1978; 92(5):p.725-728

8. Buts JP. One-hour blood xylose test: A reliable index of small bowel function. The Journal of Pediatrics.1978; 92(5):p.729-33.

9. Vinod BS, Santhi S, Krithika. Osazones of the Uncommonly Encountered Reducing Sugars. International Journal of Interdisciplinary and Multidisciplinary Studies. $2015 ;(2) 9:$ p.24-29.
10. Rafi MD. Textbook of biochemistry for medical students. $2^{\text {nd }}$ ed. Universities press (India) Pvt. Ltd; 2014:p.30.

11. Chary TM, Sharma HO, editors. Practical biochemistry for medical and dental students. $1^{\text {st }}$ ed. Noida: Jaypee;2004:p.6-7.

12. Chawla R. Practical clinical biochemistry: Methods and interpretations. $3^{\text {rd }}$ ed. Noida:Jaypee; 2006:p.35.

13. Voet D, Voet JG, Pratt CW, editors. Fundamentals of biochemistry: Life at the molecular level. $3^{\text {rd }}$ ed. Wiley;2008:p.219.

14. Rodwell VW, Bender DA, Botham KM, Kennelly PJ, Weil PA, editors. Harper's illustrated biochemistry. $30^{\text {th }}$ ed. Lange: McGraw Hill; 2015:p.152-55.

15. Ngugi MP, Njagi JM, Kibiti CM, Ngeranwa JJN, Njagi ENM. Diagnosis of Diabetes Mellitus. International Journal of Diabetes Research 2012;1(2):p.24-27. DOI: $10.5923 /$ j.diabetes.20120102.01

16. Gupta SK, Ghalaut VS, Jain A, editors. Manual of practical biochemistry for MBBS. $2^{\text {nd }}$ ed. Arya publishing company; 2013:p.23.

17. Robert MC, Arthur IA. D-Xylose Testing: A Review. Gastroenterology 1988; 95:p.223-31.

18. Wilson AM, Work TM, Bushway AA. HPLC Determination of Fructose, Glucose, and Sucrose in Potatoes. Journal of Food Science 1981;46(1):p.300-01. DOI: $10.1111 / \mathrm{j} .1365-2621$. 